\title{
Glaciological traverse across the Southern Patagonian Icefield
}

\section{Masahiro MINOWA ${ }^{1 *}$, Marius SCHAEFER ${ }^{1}$, Pedro SKVARCA ${ }^{2}$, Sumito MATOBA ${ }^{3}$ and Guisella GACITÚA ${ }^{1}$}

1 Instituto de Ciencias Físicas y Matemáticas, Universidad Austral de Chile, Valdivia, Chile

*minowa.masahiro@gmail.com

2 Glaciarium - Glacier Interpretive Center, El Calafate, Argentina

3 Institute of Low Temperature Science, Hokkaido University, Sapporo, Japan

(Received August 20, 2019; Revised manuscript accepted December 23, 2019)

\begin{abstract}
To better understand the temporal variation of the ice surface elevation and the spatio-temporal variation of snow accumulation in the accumulation area of the Southern Patagonian Icefield, we carried out a glaciological traverse in October 2018. This included measurements of surface elevation, firn layers, and sampling of snow in the accumulation areas of Glaciar Viedma and Glaciar Pío XI. The main results from the traverse are: i) during the period of 2000-2018 the surface elevation in the accumulation area of Glaciar Viedma decreased by $1.7 \mathrm{ma}^{-1}$, but increased at Glaciar Pío XI by $0.4 \mathrm{ma}^{-1}$, ii) ground-penetrating radar revealed numerous firn layers with a continuous water aquifer at $20-40 \mathrm{~m}$ depth, iii) the water isotope ratio of surface snow samples varied with wind direction. Repeating the traverse in the area will provide an opportunity to answer questions about the contrasting glacier behavior and the snow accumulation rate, a necessary step to make reliable projections of future glacier behavior in Patagonia.
\end{abstract}

Key words: Southern Patagonian Icefield, Glacier fluctuation, Accumulation

\section{Introduction}

Northern Patagonian Icefield (NPI: $\sim 3700 \mathrm{~km}^{2}$ ) and Southern Patagonian Icefield (SPI: $\sim 12,000 \mathrm{~km}^{2}$ ) are the largest temperate ice masses in the world (Meier et al., 2018), and both are losing ice at one of the fastest rates (e.g., Braun et al., 2019; Dussaillant et al., 2019). While the majority of outlet glaciers in Patagonia are shrinking, Glaciar Pío XI, the largest glacier in South America, has advanced at a rate of $42 \mathrm{ma}^{-1}$ between 1984 and 2011 (e.g., Sakakibara and Sugiyama, 2014), and has thickened by $5 \mathrm{ma}^{-1}$ in the ablation area as revealed by synthetic aperture radar data analyses (e.g., Malz et al., 2018). Foresta et al. (2018) used a radar altimetry dataset to report that thickening is occurring (even in the accumulation area) by $\sim 1 \mathrm{~m} \mathrm{a}^{-1}$ up until $1500 \mathrm{~m}$ a.s.l. Radar altimetry seems the most accurate way to measure elevation on low-contrast snow-covered terrain (Foresta et al., 2018). However, all remote sensing data have considerable associated uncertainty. Determining surface elevation change from remote sensing datasets is still challenging when the surface is covered by snow. On one hand, low contrast over snow leads to a large uncertainty in the elevation model derived from optical images (e.g., Willis et al., 2012; Sakakibara et al., 2013; Minowa et al., 2015), and on the other hand, synthetic aperture radar signals penetrate into snow, with the penetration depth depending on snow conditions (Malz et al., 2018). Therefore, the field ground-truth obtained by means of accurate devices, such as Global Navigation Satellite System (GNSS), is very important to calibrate the remote sensing data and validate the derived result for an accurate estimation of ice mass loss, particularly in the accumulation areas.

Another unique aspect of glaciers in Patagonia is the large surface mass balance gradient (e.g., Schaefer et al., 2013; 2015) and the mass loss from the ice-fronts through calving and subaqueous melting (Sakakibara and Sugiyama, 2014). While several field measurements of surface ablation (e.g., Takeuchi et al., 1995; Stuefer et al., 2007) and frontal ablation (e.g., Sugiyama et al., 2016, 2019; Minowa et al., 2018) were carried out, extensive studies of snow accumulation are still substantially lacking in Patagonia, primarily due to the extreme weather and challenging logistics, which limits an accurate estimation of snow accumulation on icefields (Schaefer et al., 2013; 2015). Several earlier studies reported the accumulation rates reconstructed from firn cores (Yamada 1987; Aristarain and Delmas, 1993; Matsuoka and Naruse, 1999; Shiraiwa et al., 2002; Schwikowski et al., 2013). The largest accumulation rate, but reasonable to balance with the surface ablation and calving, was measured by Shiraiwa et al. (2002) who obtained $11-18 \mathrm{~m} \mathrm{a}^{-1}$ w.eq. at $1760 \mathrm{~m}$ a.s.l. on 
Glaciar Tyndall, which contrasts strongly with the 1.2 $\mathrm{m} \mathrm{a}^{-1}$ w.eq. measured at $2680 \mathrm{~m}$ a.s.l. on Glaciar Perito Moreno (Aristarain and Delmas, 1993). Slightly higher but not as high as expected accumulation rate of $5.8 \mathrm{~m} \mathrm{a}^{-1}$ w.eq. was measured on high plateau (2600 $\mathrm{m}$ a.s.l.) in the accumulation area of Glaciar Pío XI, where is exposed to high westerly winds (Schwikowski et al., 2013). These contrasting rates can probably be explained by different accumulation processes such as snow erosion, drift and deposition. It is feasible that the dominant westerly wind in the region erodes the snow in the wind-exposed high plateau (e.g., Aristarain and Delmas, 1993; Schwikowski et al., 2013), depositing it in the lower part of the accumulation area (e.g., Shiraiwa et al., 2002). Recently, numerical modeling has been used to investigate accumulation over the northern and southern icefields (Schaefer et al., 2013; 2015). Comparison of accumulation rates between the model outputs and firn cores indicate good agreement, with the largest accumulation rate reported by Shiraiwa et al. (2002), but disagreement between the measurements and the model was observed for the other firn cores analyzed from SPI (Schaefer et al., 2015). One of the reasons for the disagreement comes from the different scale in the methods. While the firn core allows for reconstruction of the accumulation rate at a certain location, numerical modelling reconstructs a spatially averaged rate. Therefore, field measurements, which connect both methods, are necessary to properly understand the accumulation rate and processes.

In October 2018, we investigated the accumulation area between Glaciar Viedma and Glaciar Pío XI by measuring the snow surface elevation with a GNSS instrument, detecting firn layers using a groundpenetrating radar (GPR), and determining the physical and chemical properties of surface snow samples and at samples two snow pits. The aim of this article is to describe the overview of the scientific traverse over the SPI and present the first results.

\section{Study site}

Glaciar Viedma $\left(49^{\circ} 31^{\prime} \mathrm{S}, 73^{\circ} 00^{\prime} \mathrm{W}\right)$ covers an area of $974 \mathrm{~km}^{2}$ (Fig. 1a; De Angelis, 2014). The length of the glacier is $\sim 70 \mathrm{~km}$. The highest point of the glacier is Cerro Francisco Perito Moreno (3470 m a.s.l.), which is the highest peak of the mountain chain named Cordón Mariano Moreno (Fig. 1a). The glacier flows and calves into Lago Viedma at $250 \mathrm{~m}$ a.s.l. The equilibrium-line altitude was estimated to be $1260 \mathrm{~m}$ by analyzing the snowline at the end of mass balance season by a satellite image (De Angelis, 2014). The bedrock topography of the glacier has been reported in previous studies near the ice-front (Sugiyama et al., 2016), and in the accumulation area (Millan et al., 2019). The bathymetry of the lake near the ice-front was measured by a depth sounder recording a maximum depth of $\sim 450 \mathrm{~m}$, or $\sim 200 \mathrm{~m}$ below sea level (Sugiyama et al., 2016). In the accumulation area ice radar
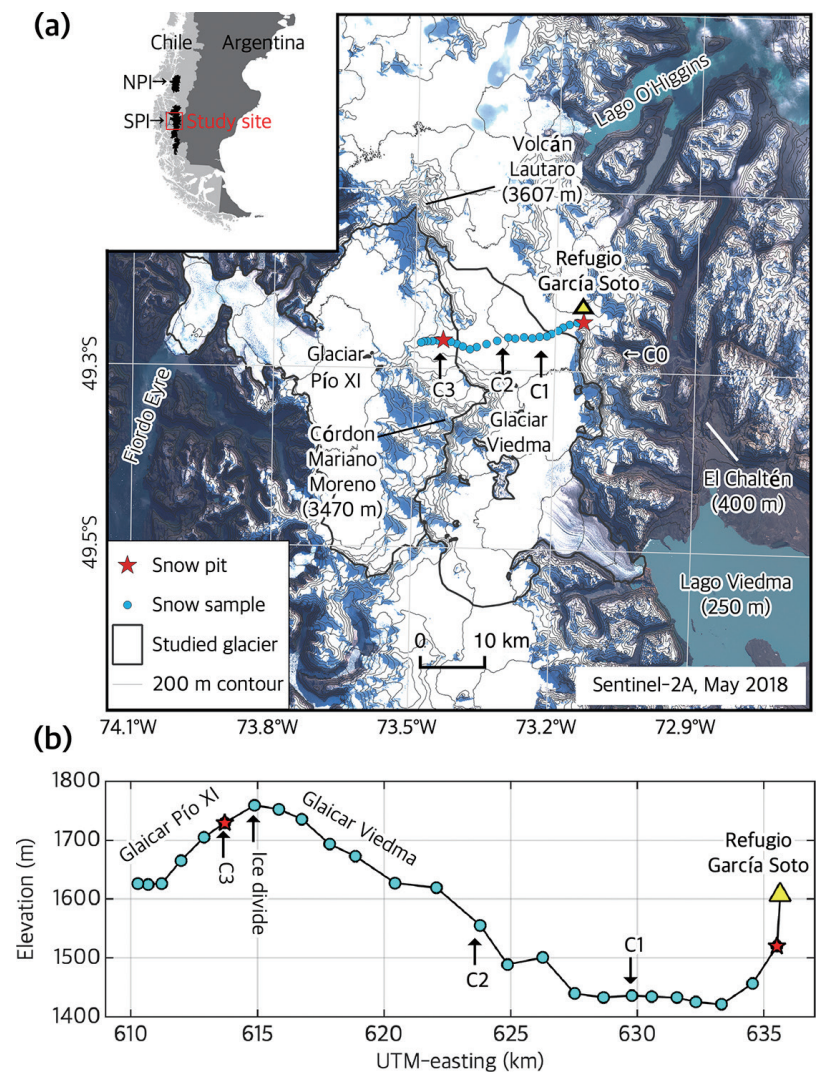

Fig. 1. Field map of the traverse. (a) A satellite image of the study region showing the traverse track. The black thick lines indicate the two studied glaciers. The contours in thin gray color show the ice surface elevation every $200 \mathrm{~m}$. (b) Elevation profile shows the places where surface snow sampling and snow pit measurements were performed. Red stars and light blue circles indicate 2 m-deep snow pit and surface sampling, respectively.

measurement revealed that some parts of the glacier are located $\sim 200 \mathrm{~m}$ below sea level with an ice thickness over 1400 m (Millan et al., 2019). Similar to most other glaciers in Patagonian icefields, Glaciar Viedma has experienced thinning and retreat over the last several decades (e.g., Rignot et al., 2003; Sakakibara and Sugiyama, 2014; Abdel Jaber et al., 2019), resulting in $-2.08 \mathrm{~km}^{3} \mathrm{a}^{-1}$ mass loss between 2000 and 2016 (Abdel Jaber et al., 2019).

Glaciar Pío XI ( $\left.49^{\circ} 08^{\prime} \mathrm{S}, 73^{\circ} 56^{\prime} \mathrm{W}\right)$ covers an area of $1234 \mathrm{~km}^{2}$ (Fig. 1a; De Angelis, 2014). The glacier is $\sim 70 \mathrm{~km}$ long and its highest point is located at Volcán Lautaro (3607 $\mathrm{m}$ a.s.l.), which is an active volcano and the highest peak in SPI (Fig. 1a). The glacier has two ice-fronts; the northern one flows into a lake (Lago Greve), and the southern front into the ocean (Fiordo Eyre). The equilibrium-line altitude is estimated to be $\sim 930 \mathrm{~m}$ (De Angelis, 2014). The ice radar measurements reported by Millan et al. (2019) indicate that in the deepest part of accumulation area the bedrock topography is $\sim 400 \mathrm{~m}$ below sea level, having in places more than $1300 \mathrm{~m}$ thick ice. Unlike other glaciers in SPI, Glaciar Pío XI has been advancing and thickening over the last several decades (e.g., Sakakibara and Sugiyama, 2014; Abdel Jaber et al., 
Table 1. List of participants, name and role in the project.

\begin{tabular}{lll}
\hline Name & Affiliation & Role \\
\hline Pedro Skvarca & Glaciarium & General coordination, weather forecast \\
Marius Schaefer & Universidad Austral de Chile & General coordination, ground support \\
Masahiro Minowa & Universidad Austral de Chile & General activities, GNSS analysis \\
Steffen Welsch & Southern Adventure Trek & Field guide and assistant \\
Sumito Matoba & Hokkaido University & Snow sample analysis \\
Guisella Gacitúa & Universidad Austral de Chile & GPR data analysis \\
Matthias Scheiter & Universidad Austral de Chile & Porter \\
Jorge Lenz & Administración de Parque Nacionales, & Porter \\
& Argentina & \\
Matías Villanueva & - & Porter \\
Carola Jozwicki & Southern Adventure Trek & Weather forecast \\
\hline
\end{tabular}

Table 2. Timetable of field activities in October 2018. BC and C0-4 stand for Base camp and camps 0-4, respectively.

\begin{tabular}{|c|c|c|c|c|c|}
\hline Day of Oct. & Location & Observations & Day of Oct. & Location & Observations \\
\hline $4-5$ & El Chaltén to $\mathrm{C} 0$ & & 16 & $\mathrm{BC}$ to $\mathrm{C} 1$ & $\begin{array}{l}\text { - GNSS measurement } \\
\text { - Surface sampling } \\
\text { - Weather measurements }\end{array}$ \\
\hline 6 & El Chaltén & & 17 & $\mathrm{C} 1$ to $\mathrm{C} 2$ & $\begin{array}{l}\text { - GNSS measurement } \\
\text { - Surface sampling } \\
\text { - Weather measurements }\end{array}$ \\
\hline 7 & El Chaltén to BC & - Install weather station & 18 & $\mathrm{C} 2$ to $\mathrm{C} 3$ & $\begin{array}{l}\text { - GNSS \& GPR survey } \\
\text { - Snow pit (Pit-2) } \\
\text { - Surface sampling } \\
\text { - Weather measurements }\end{array}$ \\
\hline 8 & $\mathrm{BC}$ & $\begin{array}{l}\text { - Surface sampling } \\
\text { - Weather measurements }\end{array}$ & 19 & $\mathrm{C} 3$ to $\mathrm{C} 1$ & $\begin{array}{l}\text { - GNSS \& GPR survey } \\
\text { - Surface sampling } \\
\text { - Weather measurements }\end{array}$ \\
\hline 9 & $\mathrm{C} 0$ to $\mathrm{BC}$ & $\begin{array}{l}\text { - Surface sampling } \\
\text { - Weather measurements }\end{array}$ & 20 & $\mathrm{C} 1$ to $\mathrm{C} 0$ & $\begin{array}{l}\text { - GNSS measurement } \\
\text { - Surface sampling } \\
\text { - Weather measurements }\end{array}$ \\
\hline 10 & $\mathrm{BC}$ & $\begin{array}{l}\text { - Surface sampling } \\
\text { - Snow pit (Pit-1) } \\
\text { - Weather measurements }\end{array}$ & 21 & $\mathrm{BC}$ to $\mathrm{C} 0$ & $\begin{array}{l}\text { - Recovering the weather } \\
\text { station }\end{array}$ \\
\hline \multirow[t]{2}{*}{$11-15$} & $\mathrm{BC}$ & $\begin{array}{l}\text { - Surface sampling } \\
\text { - Weather measurements }\end{array}$ & 22 & C0 to El Chaltén & - GNSS measurement \\
\hline & & & 23 & C0 to El Chaltén & \\
\hline
\end{tabular}


2019). The glacier volume increased by $\sim 0.89 \mathrm{~km}^{3} \mathrm{a}^{-1}$ between 2000 and 2016 (Abdel Jaber et al., 2019). It has been postulated that Pío XI is a surging glacier (e.g., Rivera et al., 1997; Wilson et al., 2016). The recent ice flow acceleration occurred in the period 1997-2000, reaching its maximum $>15 \mathrm{~m} \mathrm{~d}^{-1}$ in 2000 , as documented by Wilson et al. (2016). Yet, the trigger mechanism and surging controls remain unclear.

\section{Overview of Field Activities}

Field activity participants and their roles are listed in Table 1. A scientist and a field assistant performed the fieldwork over the icefield, and four porters helped transport cargo to Refugio García Soto (Fig. 1; Table 1). During the field campaign, a satellite communication device (InReach explorer, Garmin), was used for daily weather forecast and general communication. In the case of emergency, we would contact a helicopter agency based in Coyhaique, approximately $450 \mathrm{~km}$ north from the site.

In total, we spent 21 days between the 4th and 23rd of October in the traverse transporting materials and performing scientific measurements (Table 2). The total weight of the scientific and mountain equipment including food was about $200 \mathrm{~kg}$. All cargo was brought up by five people along Rio Eléctrico to Refugio García Soto Base Camp (BC) (Fig. 1). All the material was transported first to Camp 0 (C0), then carried up to the shelter (Fig. 1). We finished uploading all material to $\mathrm{BC}$ on October 9th and made the first snow pit near the shelter on October 10th (Fig. 1). Due to severe weather conditions, we remained at the shelter from October 11-15. We began the traverse across the icefield towards Glaciar Pío XI on the afternoon of October 16th. From BC it took three days to reach Glaciar Pío XI, camping every evening at three different sites: $\mathrm{C} 1$ on the 16th and 19th, C2 on the 17th, and C3 on the 18th (Fig. 1). Due to several deep and wide crevasses, and severe weather forecast for the coming days, we finished our field activities on October 19th and returned from $\mathrm{C} 3$ to $\mathrm{C} 1$. On the 20th, we began carrying down instruments and samples from the icefield to El Chaltén town, completing all activities on October 23rd.

\section{Scientific Measurements}

\subsection{Weather Conditions}

We installed an automatic air temperature and humidity logger (LR5001, HIOKI) near BC, located at $1600 \mathrm{~m}$ (Fig. 1). The sensor was mounted on a pole at 1.6$\mathrm{m}$ above the snow surface within a sun shield, recording every $5 \mathrm{~min}$ (Fig. 2a). In addition to the automatic station, we observed air temperature, wind speed, wind direction, and air pressure manually during the day approximately every 3 hours using a handhold meteorological meter (Kestrel 4500 pocket weather tracker) with a compass.

Air temperature was generally below $0^{\circ} \mathrm{C}$ in the first (a)

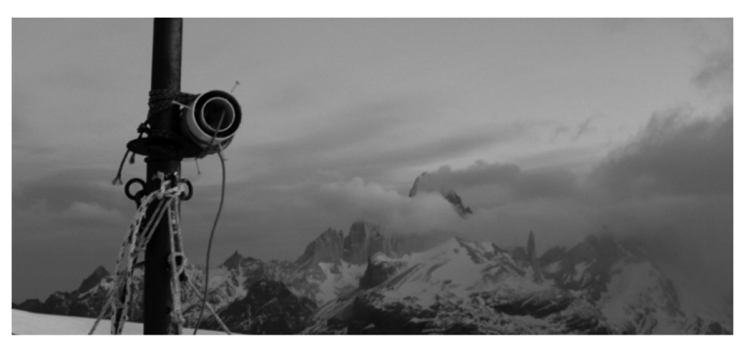

(b)

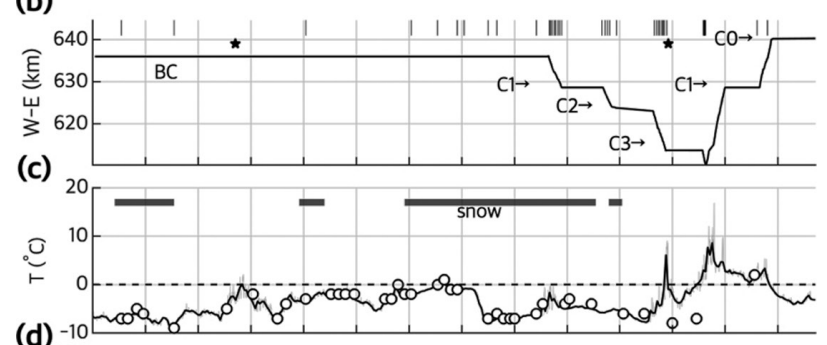

(d)

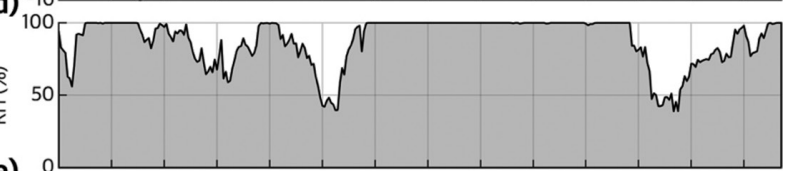

(e)

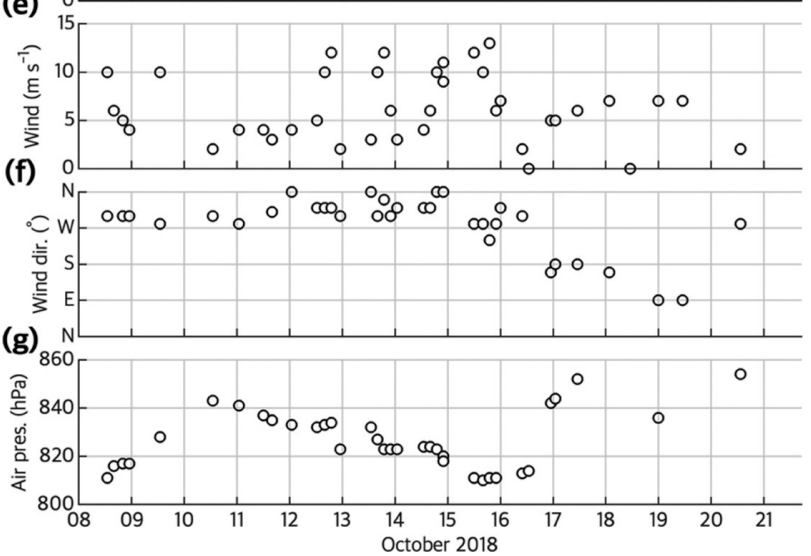

Fig. 2. Weather records during the traverse. (a) Weather station at BC. (b) Black line indicates easting of the traverse. Black star and vertical lines indicate the date of surface sampling and snow pits. (c) Air temperature, (d) relative humidity, (e) wind speed, (f) wind direction and (g) air pressure during the traverse. Temperature and humidity were measured continuously at $\mathrm{BC}$, while other parameters were measured spontaneously by Kestrel.

ten days (Fig. 2c). The mean temperature was $-3.6^{\circ} \mathrm{C}$, with a minimum of $-9.4^{\circ} \mathrm{C}$ and a maximum of $8.6^{\circ} \mathrm{C}$ (Fig. 2c). There were severe weather conditions between October 11-15 (Fig. 2). The mean wind speed was $6.3 \mathrm{~m} \mathrm{~s}^{-1}$ with dominant wind from northwest (Figs. 2e and f). Due to snowfall and snowdrift, visibility was very limited during this period. When the weather improved on October 16th, the wind direction changed abruptly from northwest to south and the air pressure increased (Figs. 2f and g). Reasonably good weather conditions for the traverse continued for four days until October 21.

\subsection{Surface Elevation}

Snow surface elevation was measured by a GNSS during the traverse (Fig. 1). We used a dual-frequency 
(a)

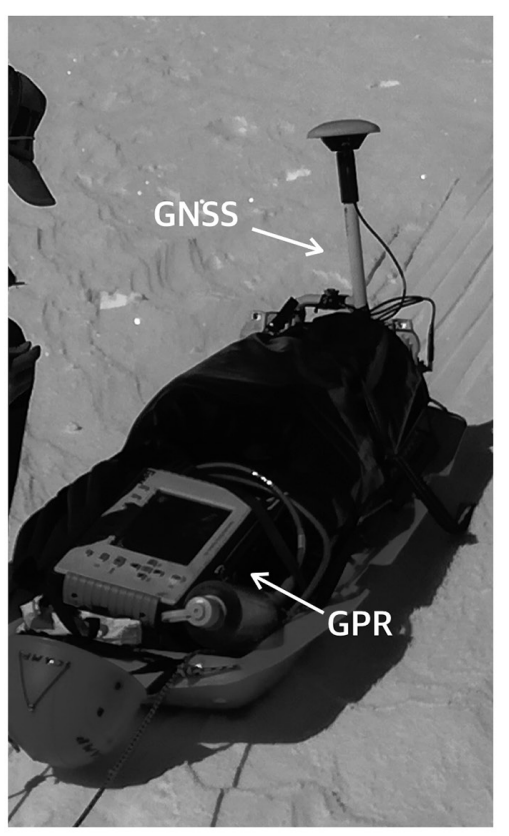

(b)

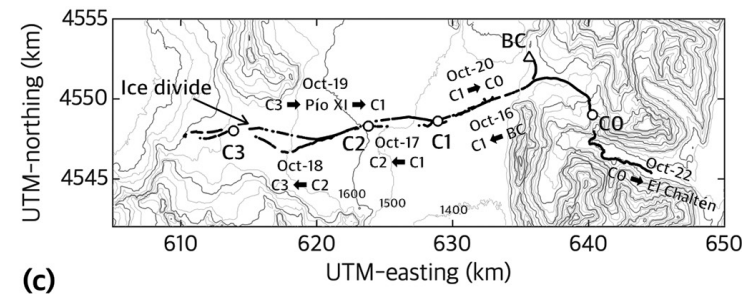

(c)

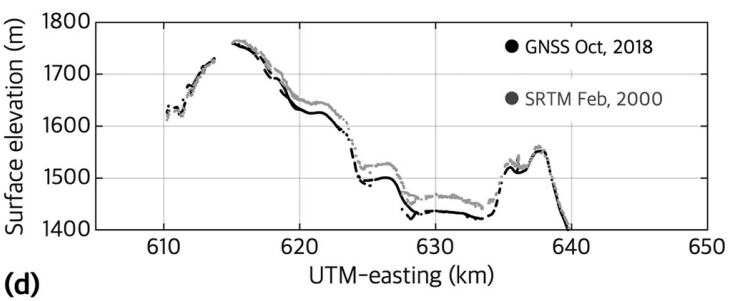

(d)

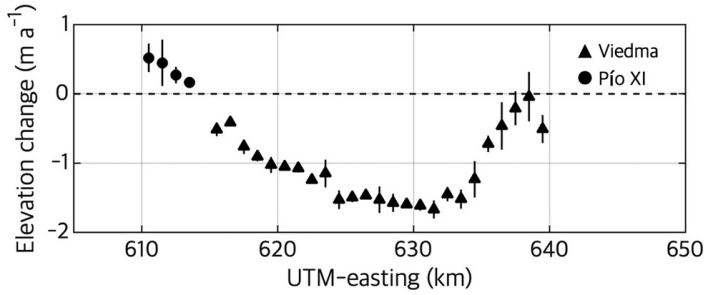

Fig. 3. Snow surface elevation measurements. (a) Sledge equipped with GNSS and GPR. (b) GNSS track during the traverse. Contours intervals are $100 \mathrm{~m}$. (c) Surface elevation of the GNSS antenna (black) and corresponding elevation obtained from SRTM DEM (grey). Horizontal black thick lines indicate where we performed GPR scanning. (d) Mean elevation change rate in Glaciar Viedma ( $\mathbf{\Delta}$ ) and Glaciar Pío XI ( ). Vertical line indicates one standard deviation of each $1 \mathrm{~km}$ bin of UTM-easting.

GNSS (GEM-1, GNSS technology) by fixing the antenna on the sledge (Fig. 3a). GNSS signal from GPS, GLONASS and GALILEO satellites were recorded every 1 sec. These signals were post-processed using RTKLIB software (http://www.rtklib.com/), and three-dimensional coordinates were calculated by the software using the kinematic method, with a fixed GNSS station located at El Chaltén (Fig. 1). The distance between the rover and the fixed GNSS station ranged between 10 and $50 \mathrm{~km}$ (Fig. 1). We only used the highest quality solutions to calculate the elevation change, resulting in gaps within the tracks (Fig. 3b). The fraction of the highest quality solution in the total solution was $49 \%$. The accuracy of three coordinates is expected to be a linear function of the baseline (Sada, 2003). For a 10-50 km baseline, the accuracy in the horizontal coordinate is $5-15 \mathrm{~mm}$ and $22-$ $110 \mathrm{~mm}$ for the vertical coordinate. The surface elevation data derived from the GNSS measurements were compared with the SRTM v3 DEM obtained in 2000 February with C-band Synthetic Aperture Radar (Fig. 3c) (Rodriguez et al., 2006). The spatial resolution of the SRTM DEM is 1 arc-second or about $30 \mathrm{~m}$. Vertical error of the DEM was evaluated by comparing the DEM with GNSS-derived elevation on the bedrock where elevation change is negligible (Fig. $3 \mathrm{~b}$ ). The error estimated to be $\pm 18.3 \mathrm{~m}$ or $\pm 0.98 \mathrm{~m} \mathrm{a}^{-1}$ from root-mean-square error. It should be noted that $\mathrm{C}$-band radar can penetrate into snow and ice up to $10 \mathrm{~m}$ (e.g., Rignot et al., 2001). All of the highest quality GNSS data were compared with the closet corresponding SRTM DEM pixel. Then, the mean elevation difference rate was calculated each $1 \mathrm{~km}$ bin of UTM-easting for each glacier.

Figure $3 \mathrm{~b}$ shows the track calculated by GNSS during the traverse. In total, we traveled over $71 \mathrm{~km}$ on snow and bedrock by ski and foot with a mean speed of $2 \mathrm{~km} \mathrm{~h}^{-1}$. The lowest and highest elevations measured over the icefield were $1420 \mathrm{~m}$ and $1760 \mathrm{~m}$, respectively (Fig. 3c). The surface of the snow decreased by up to $\sim 1.7 \mathrm{~m} \mathrm{a}^{-1}$ on Glaciar Viedma at elevations between 1420 and $1500 \mathrm{~m}$ (Fig. 3d). The rate decreased as the elevation was increasing towards the ice-divide. In contrast, we have observed that the surface elevation increased at Glaciar Pío XI shortly after crossed the ice-divide (Figs. $3 \mathrm{c}$ and $\mathrm{d}$ ). The mean thickening rate was $\sim 0.4 \mathrm{~m} \mathrm{a}^{-1}$ in the elevation between 1620 and $1760 \mathrm{~m}$ (Figs. 3c and d). These thinning and thickening rates are consistent with numbers presented in the previous study by analyzing satellite altimeter data (Foresta et al., 2018).

However, the elevation changes need to be carefully evaluated. Radar signal penetration was not considered in the elevation comparison described above (e.g., Rignot et al., 2001). If we include the $10 \mathrm{~m}$ of penetration into our differentiation, it leads to $0.56 \mathrm{~m} \mathrm{a}^{-1}$ of overestimation for the thinning of Glaciar Viedma, and an underestimation for the thickening at Glaciar Pío XI. Thus, our elevation change rates can be the upper limit for Glaciar Viedma and the lower limit for Glaciar Pío XI. In addition, we also need to consider the winter accumulation for observed thickening at Glaciar Pío XI (Fig. 3d). While the SRTM DEM was derived from the dataset obtained in February 
(a)

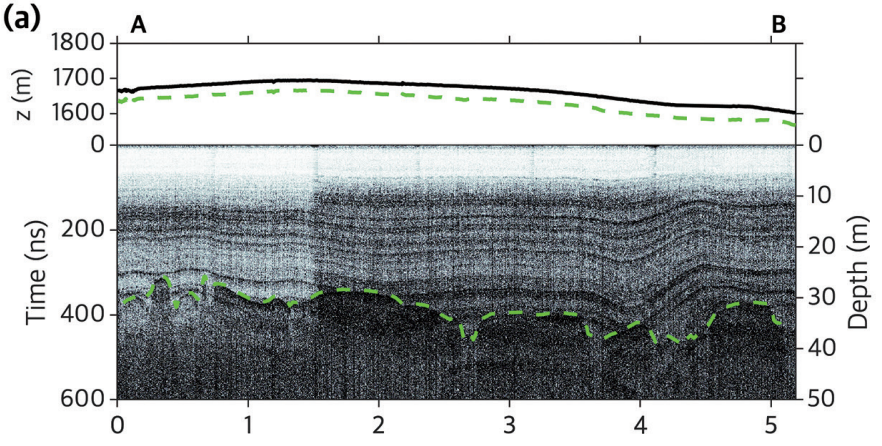

(c)

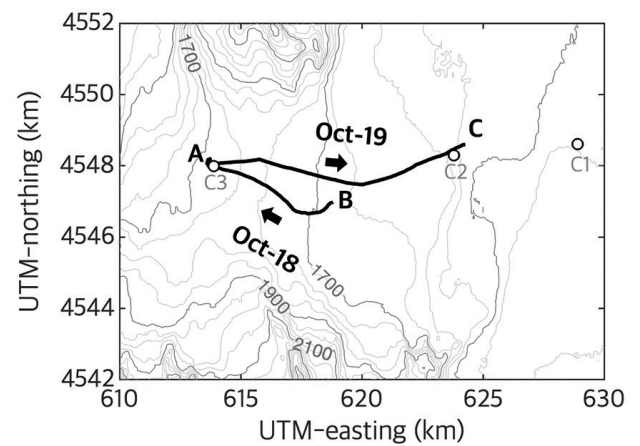

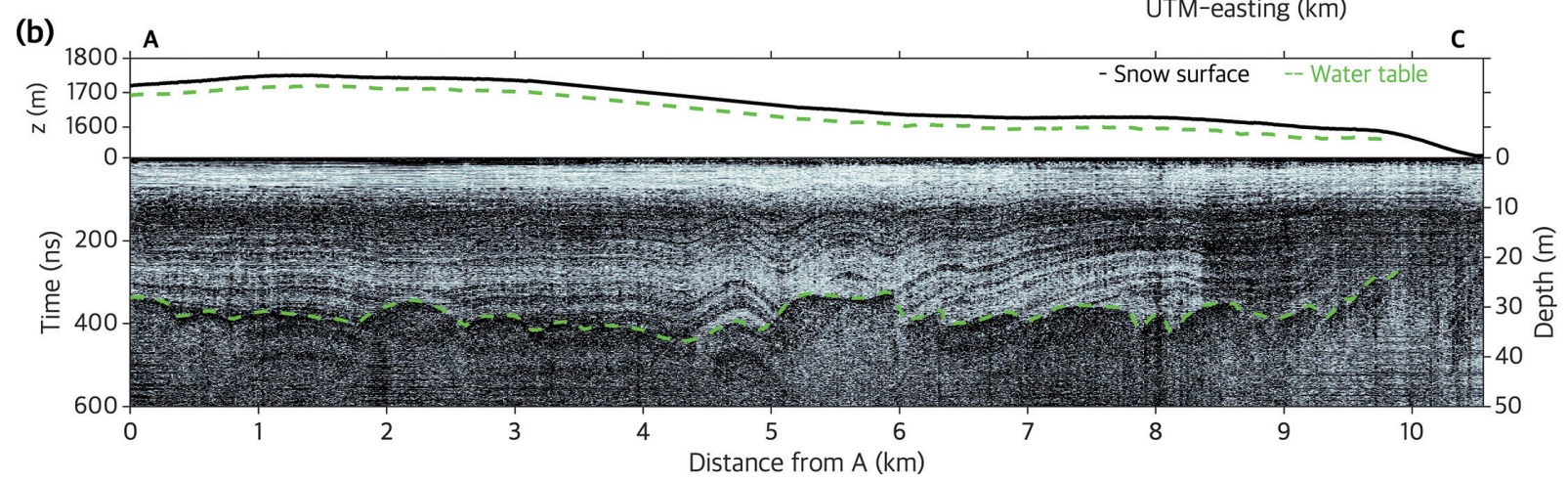

Fig. 4. Radargram along (a) line A-B on 18th and (b) line A-C on 19th. Black lines indicate snow surface elevation along the survey line. Dashed green lines highlight a possible water table. (c) Lines A-B and A-C are indicated by thick black lines on $50 \mathrm{~m}$ contour map. The black arrows indicate the direction of the GPR survey and white circles are the location of the advanced camps.

(end of austral summer), our GNSS survey was carried out in October (austral spring). If we assume that the thickening of $\sim 0.4 \mathrm{~m} \mathrm{a}^{-1}$ was due to snow accumulation over the winter, we obtain $\sim 7.2 \mathrm{~m}$ of snow accumulation on average by assuming no radar penetration in SRTM DEM. This is certainly high accumulation, but possible to occur in the region of our study according to the observed (Shiraiwa et al., 2002) and modeled (Schaefer et al., 2015) accumulation rates. Furthermore, we estimated the relatively large vertical error in SRTM DEM as \pm $0.98 \mathrm{~m} \mathrm{a}^{-1}$. More accurate measurements can be obtained by a repeat GNSS survey in the future, which will be crucial to determine the small magnitude of surface elevation change in the accumulation area, especially for Glaciar Pío XI.

\subsection{Ground-penetrating radar}

Firn layers were measured with a GPR system for approximately $15 \mathrm{~km}$ over the ice divide between Glaciar Viedma and Pío XI twice, both on October 18th and 19th (Fig. 4). The mean motion speed during the measurements was $1.7 \mathrm{~km} \mathrm{~h}^{-1}$ on the $18 \mathrm{th}$ and $2.4 \mathrm{~km} \mathrm{~h}^{-1}$ on the 19th. We used a SIR3000 system equipped with $400 \mathrm{MHz}$ central frequency antennae (GSSI Inc.), which were mounted on a sledge (Fig. 3a). Data was processed using a commercial software (ReflexW, https://www.sandmeiergeo.de/). The firn layer depths were estimated assuming an average electromagnetic wave speed of $0.172 \mathrm{~m} \mathrm{~ns}^{-1}$ based on snow density conditions at Glaciar Mocho (Schaefer et al., 2018).
Figure 4 shows radargrams acquired over the icefield on October 18th and 19th. Most notably, we observed the strongest reflection all along the traverse at depths between 20 and $40 \mathrm{~m}$ in both profiles (Figs. $4 \mathrm{a}$ and b). The mean depth of the layer was $32 \mathrm{~m}$ and $31 \mathrm{~m}$, measured on both October 18th and 19th, respectively. Overall, the depth of the layer slightly increased from $\sim 30 \mathrm{~m}$ deep at $0 \mathrm{~km}$ to $40 \mathrm{~m}$ deep at around $4 \mathrm{~km}$ on both radargrams (Fig. 4). After $5 \mathrm{~km}$, it started to decrease to $\sim 20 \mathrm{~m}$ as the elevation decreases (Fig. $4 \mathrm{~b}$ ). In addition to this, numerous layers are visible above the strongest bottom layer, especially from the surface to the boundary (Fig. 4).

A meltwater layer beneath the firn layer has been reported in the lower accumulation area of NPI (Yamada, 1987; Matsuoka and Naruse, 1999) and SPI (Shiraiwa et al., 2002). Yamada (1987) found a water-soaked layer between depths of 19.7 and $24.9 \mathrm{~m}$ and an aquifer between 24.9 and $26.7 \mathrm{~m}$ in the $37.6 \mathrm{~m}$ long firn core drilled in Glaciar San Rafael, NPI, at 1300 m. Matsuoka and Naruse (1999) obtained a firn core at slightly higher elevation at $1500 \mathrm{~m}$ of Glaciar Nef. The authors also reported a water-soaked layer below $13.4 \mathrm{~m}$. In SPI, Shiraiwa et al. (2002) found the water-soaked layer deeper in snow than the studies in NPI. The layer was detected at 43-m firn depth in Glaciar Tyndall at $1760 \mathrm{~m}$ a.s.l. (Shiraiwa et al., 2002). Based on these studies, we assumed that the strong boundary detected is a water table, and below it a water-soaked layer or aquifer (Fig. 4). Because the layer is observed continuously along our track, the 


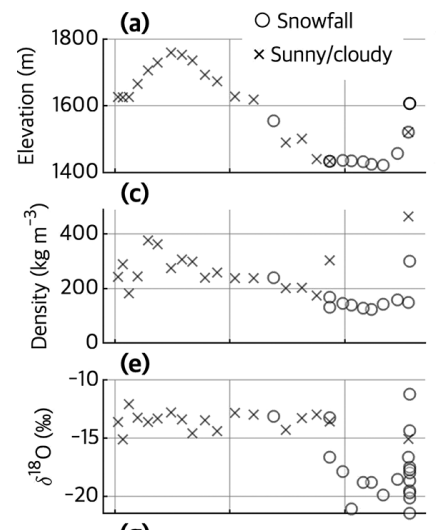

(b)

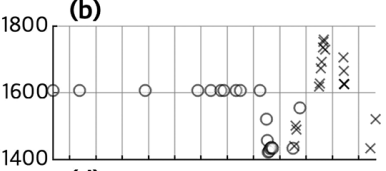

(d)

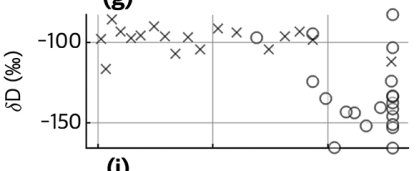

(i)

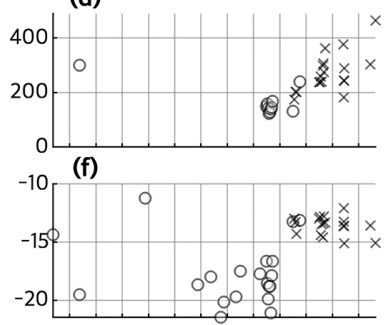

(h)

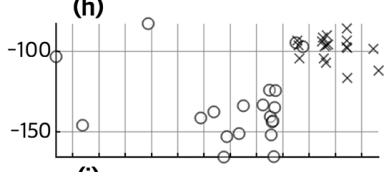

(j)

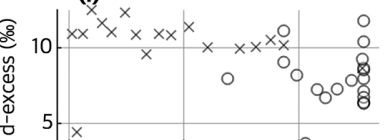

(k)
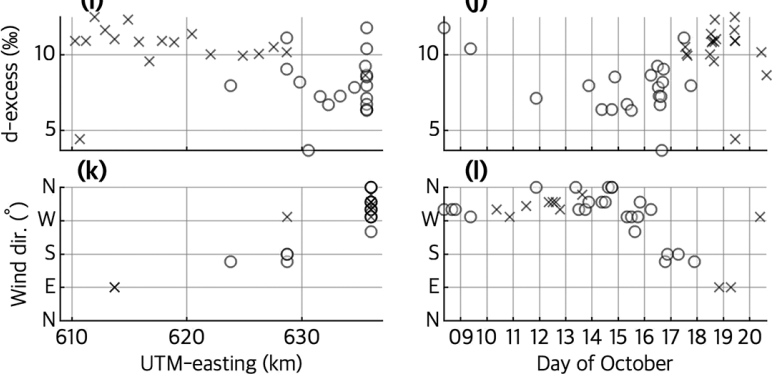

Fig. 5. Spatial and temporal variations in surface snow density and chemical properties. (a, b) Location and elevation of the snow sampling. Spatial and temporal variations in (c, d) snow density, (e, f) $\delta^{18} \mathrm{O},(\mathrm{g}, \mathrm{h}) \delta \mathrm{D}$, and $(i, j) d$-excess. $(k, 1)$ For comparison, the wind direction was indicated. Open circles and crosses indicate whether there was snowfall or not during snow sampling.

water-soaked layer or aquifer could be a common feature of the icefields at this elevation range.

The numerous layers are visible above the strong boundary (Fig. 4). Similar layers in firn were widely reported in the accumulation area in Greenland (e.g., Dunse et al., 2008) and other glaciated regions in the world (e.g., Pälli et al., 2002; Sold et al., 2015). These studies used the firn layers to reconstruct annual accumulation by synchronizing layers detected by GPR survey and chemical properties of the corresponding firn. However, a possible difference between the layers in Patagonian icefields and other regions is that the observed layers are a result of individual snowfall events or seasonal snow accumulation rather than annual snow accumulation. Together with the large snow accumulation expected in the region and strong snow melting during the austral summer suggested by the water table, we should be very cautious when trying to measure the annual accumulation from GPR survey and chemical analyses of the firn in Patagonia than in other regions.

\subsection{Surface Snow and Snow pit}

Surface snow was sampled at BC and approximately every $1 \mathrm{~km}$ along the traverse line (Fig. 1). The samples

(a)

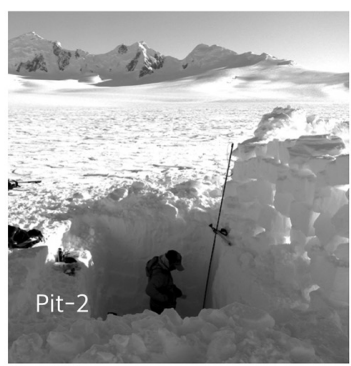

(d) Pit-1: 1 m-deep

(b) Pit-1: $1521 \mathrm{~m}$

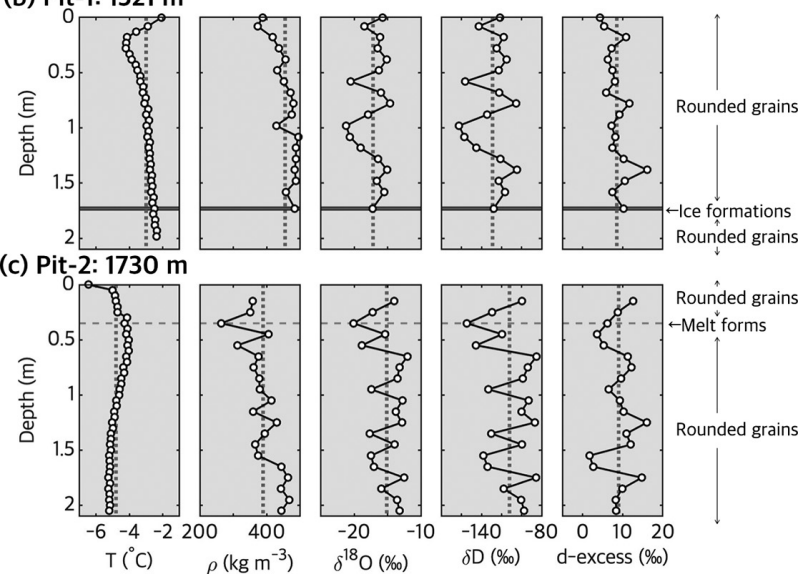

Fig. 6. Snow pit profiles. (a) A photograph of the snow pit at the ice divide. Snow temperature and density profile of two-meter-deep snow pit at (b) the easternmost site and (c) the ice divide, as indicated in Figure 1. Horizontal thick and dashed lines indicate ice formations and melt forms. The vertical dotted lines indicate the mean value of the properties. The rest were rounded grains. Snow crystals at (d) $1 \mathrm{~m}$ deep in Pit-1 and (e) $1.5 \mathrm{~m}$ deep in Pit-2. The grid size of the background plate is in $1 \mathrm{~mm}$ for each.

were collected at $\mathrm{BC}$ between October 8-16th, and along the traverse line between October 16-20th (Fig. 5 and Table 1). Surface snow was sampled 2-3 times with a $100 \mathrm{~cm}^{3}$ sampler. Mean snow density was obtained by measuring the weight of sampled snow. In total, we sampled surface snow at 26 sites within an elevation range between $1420 \mathrm{~m}$ and $1760 \mathrm{~m}$ (Fig. 5a). At two locations, we also performed 2-m-deep snow pit measurements (Fig. 6): the easternmost sampling site (Pit1) at $1521 \mathrm{~m}$ on October 10th, and on the ice-divide between Glaciar Viedma and Glaciar Pío XI (Pit-2) at $1730 \mathrm{~m}$ on October 18th. In each pit we measured snow density, temperature, layers and crystals morphology. Every $10 \mathrm{~cm}$, we sampled snow twice. The sampled snow was melted out after sampling and stored in a $50 \mathrm{ml}$ plastic sampling bottle. The water was analyzed for water isotopes $\delta^{18} \mathrm{O}, \delta \mathrm{D}$ and d-excess. The stable oxygen and deuterium isotope composition of sampled water were measured by a water isotope analyzer (Picarro L2120-i, Picarro Inc., Santa Clara, CA, USA) with an evaporating device (Picarro, A0212 vaporizer) at the Institute of Low Temperature Science, Hokkaido University.

Figure $5 \mathrm{c}$ shows the density of surface snow from east to west. Since snow precipitation occurred between October 13-17, this is expected to be new snow (Fig. 2c). 
The mean surface density was $232 \mathrm{~kg} \mathrm{~m}^{-3}$ with a minimum of $124 \mathrm{~kg} \mathrm{~m}^{-3}$ and maximum density of $464 \mathrm{~kg} \mathrm{~m}^{-3}$ (Fig. 5c). The density increased as we moved west (Fig. 5c) and elevation increased (Fig. 5a).

The chemical properties varied more with the date of snow sample than the location (Figs. 5e-j). The variations in chemical properties seem to be related to wind direction (Fig. 51). For example, $\delta^{18} \mathrm{O}$ increased by $5 \%$ between October 16-17 after snow precipitation overnight (Figs. 5e and f), when the wind direction changed from northwest on the 16th to south on the 17th (Fig. 5l). The mean $\delta^{18} \mathrm{O}, \delta \mathrm{D}$ and d-excess were $-15.72 \%$, $-116.74 \%$, and $9.08 \%$, respectively (Figs. $5 \mathrm{e}^{-\mathrm{j}}$ ).

Heavier isotope ratios in the western side of the icefield compared to those in the eastern side are expected, because the climate is generally controlled by westerly wind (Garreaud et al., 2013). Heavier isotopes precipitate faster than lighter isotopes when air mass is uplifted by the Andes (Stern and Blisniuk, 2002). A trajectory analysis of moisture sources suggests that the dominant moisture comes from the South Pacific Ocean from $80-160^{\circ} \mathrm{W}$ and $30-60^{\circ} \mathrm{S}$ on average between 1979 and 2017 (Langhamer et al., 2018). However, surface snow isotopes show that it varied not clearly with location from east to west (Fig. 5). It varied more clearly after the precipitation occurred between October 15-18, which had different wind directions - first from the west then south (Fig. 5). This result implies that such variability arises from different moisture sources of air mass. Thus, a longterm surface snow sampling would help to understand how moisture sources are transported from the ocean.

Figure 6 shows the snow temperature and density profiles at two snow pits. In Pit-1, the snow temperature was the highest at the surface $\left(-2.07^{\circ} \mathrm{C}\right)$, decreased to $-4.22^{\circ} \mathrm{C}$ at $0.3 \mathrm{~m}$ depth, and gradually increased to $-2.37^{\circ} \mathrm{C}$ at the bottom (Fig. 6b). Snow density increased with depth from $388 \mathrm{~kg} \mathrm{~m}^{-3}$ at the surface to $494 \mathrm{~kg} \mathrm{~m}^{-3}$ at $1 \mathrm{~m}$ depth, and similar density below. The mean temperature and density were $-3.0^{\circ} \mathrm{C}$ and $455 \mathrm{~kg} \mathrm{~m}^{-3}$, respectively. At a depth of 1.72 and $1.74 \mathrm{~m}$, we observed $5 \mathrm{~mm}$ thin ice formations, but the other parts were rounded grains (Fig. 6d). In Pit-2, the snow temperature profile was different (Fig. 6c). The coldest temperature of $-6.45^{\circ} \mathrm{C}$ was measured at the surface. It increased to $-4.3^{\circ} \mathrm{C}$ at $0.3 \mathrm{~m}$ depth, where we observed $1 \mathrm{~cm}$ thick melt forms (Fig. 6c). Further down, the snow temperature decreased to $-5.15^{\circ} \mathrm{C}$ at $1.45 \mathrm{~m}$ depth, staying similar towards the bottom. In comparison to Pit-1, the snow density increased more gradually from the surface $\left(359 \mathrm{~kg} \mathrm{~m}^{-3}\right)$ to the bottom $\left(445 \mathrm{~kg} \mathrm{~m}^{-3}\right)$. The lowest density $\left(264 \mathrm{~kg} \mathrm{~m}^{-3}\right)$ was measured at the same depth as melt forms (Fig. 6c). The mean temperature and density were $-4.8^{\circ} \mathrm{C}$ and $389 \mathrm{~kg} \mathrm{~m}^{-3}$, respectively, i.e. colder and less dense compared with Pit-1. The density difference between Pit-1 and Pit-2 is inconsistent with the relationship between snow density and elevation obtained for the surface snow samples (Fig. 5c). Despite Pit-2 being $200 \mathrm{~m}$ higher, we measured lower mean snow density at Pit-1 (Fig. 6).

The chemical properties showed strong variation dependent on depths (Figs. 6b and c). Their variation ranged between -21.22 and $-12.04 \%$ for $\delta^{18} \mathrm{O},-162.6$, and $-85.06 \%$ for $\delta \mathrm{D}$, and 1.75 and $16.14 \%$ for d-excess. Since we observed that large variation of these chemical properties depends on the day snow was sampled (Fig. 5), these layers preserve the chemical properties of each precipitation event.

The mean chemical properties were consistently different (Fig. 6). At Pit- $1, \delta^{18} \mathrm{O}, \delta \mathrm{D}$ and d-excess were -17.2 , -129.0 , 8.5\%o, respectively. At Pit-2 they were slightly lower, with $\delta^{18} \mathrm{O}, \delta \mathrm{D}$ and d-excess of -15.15 , -112.2 , 9.0\% , respectively. These results are consistent with the expected general accumulation pattern in the region. Since heavier water isotopes precipitate faster than lighter water isotopes, the observed difference between the snow pits indicates that the dominant precipitation pattern is west to east.

\section{Conclusions and Outlook}

To better understand the glaciers' fluctuation in the accumulation areas of Patagonian icefields, we have carried out a glaciological traverse in the Southern Patagonian Icefield. Snow surface elevation, firn layers and chemical snow properties were measured between Glaciar Viedma and Glaciar Pío XI, which are the largest and second largest glaciers in South America.

For three weeks in October 2018, only four days had reasonable weather conditions for a scientific traverse. The other periods were dominated by strong westerly winds with a mean speed of $6.3 \mathrm{~m} \mathrm{~s}^{-1}$, accompanied by snow precipitation. From our traverse three intriguing findings arise:

i) GNSS measurements revealed a contrasting elevation change between Glaciar Viedma and Glaciar Pío XI during the period of 2000-2018. While a large thinning rate of up to $1.7 \mathrm{~m} \mathrm{a}^{-1}$ was observed in Glaciar Viedma, a thickening rate of up to $0.4 \mathrm{ma}^{-1}$ was detected in Glaciar Pío XI. These results are consistent with the recently reported surface elevation changes based on remote sensing datasets analyses. A repeat measurement will be useful for an accurate estimation of surface elevation change, as well as calibration and validation of remote sensing datasets.

ii) Numerous firn layers were measured from the snow surface to $20-40 \mathrm{~m}$ depth. Below that, we detected a continuous strong reflector along the routes which could be a water table. The existence of water implies that meltwater at this elevation does not drain immediately after melting in summer.

iii) An important variability of the chemical properties snow was observed. Our data obtained from surface samples suggests that these properties might depend on wind direction, which would imply that this variability is caused by the different air moisture sources. 
The mean isotopic composition value obtained from two snow pits indicates that the water molecules were heavier at the western snow pit site.

The results of our fieldwork reveal several new aspects of glacier elevation change and accumulation processes in the accumulation area of the Southern Patagonian Icefield. A repetition of the measurement, including GNSS and GPR survey, snow sampling, firn core drilling and weather observations will provide additional data to improve our understanding of the elevation changes and accumulation processes and will help to understand better the projections of the future evolution of the Patagonian icefields.

\section{Acknowledgements}

We sincerely thank Steffen Welsch, Matthias Scheiter, Jorge Lenz, Matías Villanueva and Carola Jozwicki for their fieldwork assistance in the harsh environment. We also thank Shin Sugiyama and Gino Casassa for loaning GNSS and GPR for the expedition. Takayuki Shiraiwa shared his experiences in the accumulation area at Glaciar Tyndall, which helped us to plan our field activities. Shuntaro Hata helped to ship instruments from Japan to Chile. We thank Corp Nacional Forestal (CONAF) for providing the space at García Soto shelter and their helicopter support in case of emergency. English text was corrected by Ariah Kidder. The manuscript was handled by Scientific Editor, Takayuki Nuimura, and carefully reviewed by two anonymous reviewers. The study was supported by FONDECYT regular grant 2018-2022 (\#1180785). MM was supported by JSPS Overseas Research Fellowship 2018-2020 (\#201860152).

\section{References}

Abdel Jaber, W., Rott, H., Floricioiu, D., Wuite, J. and Miranda, N. (2019): Heterogeneous spatial and temporal pattern of surface elevation change and mass balance of the Patagonian ice fields between 2000 and 2016. The Cryosphere, 13 (9), 2511-2535, doi:10.5194/tc-13-2511-2019.

Aristarain, A. J. and Delmas, R. J. (1993): Firn-core study from the southern Patagonia ice cap, South America. J. Glaciol., 39 (132), 249-254, doi:10.1017/S0022143000015914.

Braun, M. H., Malz, P., Sommer, C., Farías-Barahona, D., Sauter, T., Casassa, G., Alvaro, S., Skvarca, P. and Seehaus, T. C. (2019): Constraining glacier elevation and mass changes in South America. Nat. Clim. Change, 9 (2), 130, doi:10.1038/ s41558-018-0375-7.

De Angelis, H. (2014): Hypsometry and sensitivity of the mass balance to changes in equilibrium-line altitude: the case of the Southern Patagonia Icefield. J. Glaciol., 60 (219), 14-28, doi:10.3189/2014JoG13J127.

Dunse, T., Eisen, O., Helm, V., Rack, W., Steinhage, D. and Parry, V. (2008): Characteristics and small-scale variability of GPR signals and their relation to snow accumulation in Greenland's percolation zone. J. Glaciol, 54 (185), 333-342. doi:10.3189/002214308784886207.

Dussaillant, I., Berthier, E., Brun, F., Masiokas, M., Hugonnet, R., Favier, V., Rabatel, A., Pitte, P. and Ruiz, L. (2019): Two decades of glacier mass loss along the Andes. Nat. Geosci.,
21, 1-7, doi:10.1038/s41561-019-0432-5.

Foresta, L., Gourmelen, N., Weissgerber, F., Nienow, P., Williams, J.J., Shepherd, A., Drinkwater, M.R. and Plummer, S. (2018): Heterogeneous and rapid ice loss over the Patagonian Ice Fields revealed by CryoSat-2 swath radar altimetry. Remote Sens. of Environ., 21, doi:10.1016/j.rse.2018.03.041.

Garreaud, R., Lopez, P., Minvielle, M. and Rojas, M. (2013): Largescale control on the Patagonian climate. J. Clim., 26 (1), 215230, doi:10.1175/JCLI-D-12-00001.1.

Langhamer, L., Sauter, T. and Mayr, G. J. (2018): Lagrangian Detection of Moisture Sources for the Southern Patagonia Icefield (1979-2017). Front. Earth Sci., 6, 219, doi:10.3389/ feart.2018.00219.

Malz, P., Meier, W., Casassa, G., Jaña, R., Skvarca, P. and Braun, M. H. (2018): Elevation and mass changes of the Southern Patagonia Icefield derived from TanDEM-X and SRTM Data. Remote Sens., 10 (2), 188, doi:10.3390/rs10020188.

Matsuoka, K. and Naruse, R. (1999): Mass balance features derived from a firn core at Hielo Patagonico Norte, South America. Arct. Antarct. Alp. Res., 31 (4), 333-340, doi:10.1080 /15230430.1999.12003318

Meier, W. J. H., Grießinger, J., Hochreuther, P. and Braun, M. H. (2018): An updated multi-temporal glacier inventory for the Patagonian Andes with changes between the little ice age and 2016. Front. Earth Sci., 6 (May), doi: 10.3389/ feart.2018.00062.

Millan, R., Rignot, E., Rivera, A., Martineau, V., Mouginot, J., Zamora, R., Uribe, J., Lenzano, G., De Fleurian, B., Li, X., Gim, Y. and Kirchner, D. (2019): Ice thickness and bed elevation of the Northern and Southern Patagonian Icefields. Geophys. Res. Lett., 46 (12), 6626-6635, doi:10.1029/2019GL082485.

Minowa, M., Sugiyama, S., Sakakibara, D. and Sawagaki, T. (2015): Contrasting glacier variations of Glaciar Perito Moreno and Glaciar Ameghino, southern Patagonia Icefield. Ann. Glaciol., 56 (70), 26-32, doi:10.3189/2015AoG70A020.

Minowa, M., Podolskiy, E. A., Sugiyama, S., Sakakibara, D. and Skvarca, P. (2018): Glacier calving observed with time-lapse imagery and tsunami waves at Glaciar Perito Moreno, Patagonia. J. Glaciol., 64 (245), 362-376, doi:10.1017/jog. 2018.28.

Pälli, A., Kohler, J. C., Isaksson, E., Moore, J. C., Pinglot, J. F., Pohjola, V. A. and Samuelsson, H. (2002): Spatial and temporal variability of snow accumulation using groundpenetrating radar and ice cores on a Svalbard glacier. $J$. Glaciol., 48 (162), 417-424, doi:10.3189/172756502781831205.

Rivera, A., Aravena, J.C. and Casassa, G. (1997): Recent fluctuations of Glaciar Pío XI, Patagonia: discussion of a glacial surge hypothesis. Mt. Res. Dev., 17 (4), 309-322, doi:10.2307/ 3674021 .

Rodriguez, E., Morris, C. S. and Belz, J. E. (2006): A global assessment of the SRTM performance. Photogramm. Eng. Remote Sens., 72 (3), 249-260, doi:10.14358/PERS.72.3.249.

Rignot, E., Echelmeyer, K. and Krabill, W. (2001): Penetration depth of interferometric synthetic-aperture radar signals in snow and ice. Geophys. Res. Lett., 28 (18), 3501-3504, doi:10.1029/2000GL012484.

Rignot, E., Rivera, A. and Casassa, G. (2003): Contribution of the Patagonia Icefields of South America to Sea Level Rise. Science, 302 (5644), 434-437, doi:10.1126/science.1087393.

Sada, T. (2003): GPS positioning technique. Ohm-Sha.

Sakakibara, D., Sugiyama, S., Sawagaki, T., Marinsek, S. and Skvarca, P. (2013): Rapid retreat, acceleration and thinning of Glaciar Upsala, Southern Patagonia Icefield, initiated in 2008. Ann. Glaciol., 54 (63), 131-138, doi:10.3189/2013AoG63A236.

Sakakibara, D. and Sugiyama, S. (2014): Ice-front variations and speed changes of calving glaciers in the Southern Patagonia Icefield from 1984 to 2011. J. Geophys. Res.: Earth Surf., 119 (11), 2541-2554, doi:10.1002/2014JF003148.

Schaefer, M., Machguth, H., Falvey, M. and Casassa, G. (2013): Modeling past and future surface mass balance of the Northern Patagonia Icefield. J. Geophys. Res.: Earth Surf., 118 (2), 571-588, doi:10.1002/jgrf.20038. 
Schaefer, M., Machguth, H., Falvey, M., Casassa, G. and Rignot, E. (2015): Quantifying mass balance processes on the Southern Patagonia Icefield. The Cryosphere, 9, 25-35, doi:10.5194/tc-925-2015.

Shaefer, M., Sheiter, M., Flandez, E., Fonseca, D., Gacitua, G., Fernandoy, F., Pable, I and Casassa, G. (2018): Glaciological studies in the Mocho Glacier, XV Congreso Geologico Chileno.

Schwikowski, M., Schläppi, M., Santibañez, P., Rivera, A. and Casassa, G. (2013): Net accumulation rates derived from ice core stable isotope records of Pío XI glacier, Southern Patagonia Icefield. The Cryosphere, 7 (5), 1635-1644, doi: 10.5194/tc-7-1635-2013

Shiraiwa, T., Kohshima, S., Uemura, R., Yoshida, N., Matoba, S., Uetake, J. and Godoi, M. A. (2002): High net accumulation rates at Campo de Hielo Patagónico Sur, South America, revealed by analysis of a $45.97 \mathrm{~m}$ long ice core. Ann. Glaciol., 35, 84-90, doi:10.3189/172756402781816942.

Sold, L., Huss, M., Eichler, A., Schwikowski, M. and Hoelzle, M. (2015): Unlocking annual firn layer water equivalents from ground-penetrating radar data on an Alpine glacier. The Cryosphere, 9 (3), 1075-1087, doi:10.5194/tc-9-1075-2015.

Stern, L. A. and Blisniuk, P. M. (2002): Stable isotope composition of precipitation across the southern Patagonian Andes. $J$. Geophys. Res.: Atmos., 107 (23), doi:10.1029/2002JD002509.

Stuefer, M., Rott, H. and Skvarca, P. (2007): Glaciar Perito Moreno, Patagonia: Climate sensitivities and glacier characteristics preceding the 2003/04 and 2005/06 damming events. $J$.
Glaciol., 53 (180), 3-16, doi:10.3189/ 172756507781833848.

Sugiyama, S., Minowa, M., Sakakibara, D., Skvarca, P., Sawagaki, T., Ohashi, Y., Naito, N. and Chikita, K. (2016): Thermal structure of proglacial lakes in Patagonia. J. Geophys. Res.: Earth Surf., 121 (12), 2270-2286, doi:10.1002/2016JF004084.

Sugiyama, S., Minowa, M. and Schaefer, M. (2019): Underwater ice terrace observed at the front of Glaciar Grey, a freshwater calving glacier in Patagonia. Geophys. Res. Lett., 46 (5), 2602-2609, doi:10.1029/2018GL081441.

Takeuchi, Y., Naruse, R. and Satow, K. (1995): Characteristics of heat balance and ablation on Moreno and Tyndall glaciers, Patagonia, in the summer 1993/94. Bull. Glacier Res., 13 $45-56$.

Willis, M. J., Melkonian, A. K., Pritchard, M. E. and Rivera, A. (2012): Ice loss from the Southern Patagonian Ice Field, South America, between 2000 and 2012. Geophys. Res. Lett., 39 (17), 1-6, doi:10.1029/2012GL053136.

Wilson, R., Carrión, D. and Rivera, A. (2016): Detailed dynamic, geometric and supraglacial moraine data for Glaciar Pio XI, the only surge-type glacier of the Southern Patagonia Icefield. Ann. Glaciol., 57 (73), 119-130, doi:10.1017/ aog.2016.32.

Yamada, T. (1987): Glaciological characteristics revealed by $37.6 \mathrm{~m}$ deep core drilled at the accumulation area of SanRafael Glacier, the Northern Patagonia Icefield. Bull. Glacier Res., 4, 59-68. 